\title{
Keragaman genetik ikan rono Adrianichthys oophorus (Kottelat, 1990) spesies endemik di Danau Poso Sulawesi Tengah berdasarkan truss morphometric dan sekuen gen cytochrome C oxidase subunit 1 (COI)
}

[Genetic diversity of egg-carrying bunting, Adrianihcthys oophorus (Kottelat, 1990) endemic species of Lake Poso Central Sulawesi using truss morphometrics and sequens of cytochrome c oxidase subunit I gene (COI)]

\author{
Wartono Hadie ${ }^{1 \bowtie}$, Meria Tirsa Gundo ${ }^{2}$, Lies Emmawati ${ }^{1}$ \\ ${ }^{1}$ Pusat Riset Perikanan \\ Jl. Ragunan No. 20, Pasar Minggu 12540. \\ ${ }^{2}$ Program Studi Pendidikan Biologi Fakultas Keguruan dan Ilmu Pendidikan \\ Universitas Sintuwu Maroso Poso \\ Jln. Pulau Timor No. 1, Poso 94619
}

Diterima: 5 Mei 2017; Disetujui: 18 Juli 2017

\begin{abstract}
Abstrak
Ikan endemik berperan sebagai indikator suatu populasi jenis ikan yang unik dan bermanfaat sebagai spesies kunci dalam upaya konservasi. Ikan rono (Adrianichthys oophorus) adalah jenis ikan endemik di Danau Poso yang perlu dilindungi dari ancaman kepunahan. Penelitian ini bertujuan untuk mengevaluasi keragaman morfometrik dan molekuler ikan rono sebagai dasar dalam strategi konservasi ikan endemik tersebut. Sampel ikan dikoleksi dari tiga populasi, yaitu populasi dari Tolombo, Taipa, dan Tentena. Sampel ikan sebanyak 30 ekor dari masing-masing lokasi diukur secara morfometrik menggunakan metode truss morphometric dan dianalisis dengan analisis komponen utama. Secara molekuler sampel ikan dianalisis sekuensing DNA menggunakan gen cytochrome C oxidase subunit 1 (COI). Hasil analisis menunjukkan bahwa populasi ikan rono di Danau Poso secara morfometrik dan molekuler memiliki keragaman yang berbeda. Secara morfometrik terdapat 12 karakter yang menjadi karakter dasar tiga populasi ikan rono ( $>0,05)$, sebanyak tiga karakter akan menjadi karakter yang beradaptasi terhadap lingkungan $(p<0,05)$ dan 11 karakter telah beradaptasi dengan lingkungan $(\mathrm{p}<0,01)$. Hasil analisis morfometrik dan molekuler antar ketiga populasi terlihat sinkron. Populasi Tentena secara morfometrik dan molekuler terpisah dengan populasi lainnya yang berarti memiliki perbedaan nyata pada tingkat DNA dan morfometrik. Implikasi hasil penelitian ini memberikan indikasi bahwa strategi konservasi ikan rono dapat dilakukan dengan memulihkan kembali keragaman gen total ( $g$ en pool). Pemulihan gen pool dapat dilakukan melalui perkawinan silang antar tiga populasi yang berbeda, sehingga terjadi aliran gen dan meningkatkan fitness yang akan menjaga populasi ikan rono sebagai jenis endemik tetap lestari.
\end{abstract}

Kata penting: ikan rono, keragaman, genetik, konservasi

\begin{abstract}
Endemic fish acts as an indicator of a unique and useful fish species population as a key species in conservation efforts. Egg-carrying Buntingi (Adrianichthys oophorus) is an of endemic fish species in Poso Lake that needs to be protected from extinction. This study aims to evaluate the morphometric and molecular diversity of rono fish as a basis in the endemic fish conservation strategy. The samples of fish are collected from three populations, namely Tolombo, Taipa, and Ten-tena. A total of 30 fish collected samples from each location are morphometrically measured using the truss morpho-metric method and analyzed applying principle component analysis. The fish samples are molecularly analyzed DNA sequencing using COI. The result of the analysis shows that rono fish populations in Poso lake morphometrically and molecularly have different diversity. In morphometrics, there are 12 characters which are the basic characters of three rono fish populations ( $p>0.05)$, as many as three characters will become characters adapting to an environment $(p<0.05)$, and 11 characters have adapted to an each environments $(p<0.01)$. The results of the morphometric and mole-cular analysis between the three populations are appearing synchronous. The Tentena population is different from other populations, showing a significant difference in DNA level. The implication of the results of this study indicates that the rono fish conservation strategy can be adopted by restoring the total gene pool. Gene pool recovery can be conducted through cross-breeding of three different populations, resulting in gene flow and increased fitness that will keep the population of rono fish as a sustainable endemic species.
\end{abstract}

Keywords: Egg-carrying Buntingi, diversity, genetic, conservation

$\square$ Penulis korespondensi

Alamat surel: tono_hadi@yahoo.com 


\section{Pendahuluan}

Ikan rono, Adrianichthys oophorus (Kottelat, 1990) merupakan ikan endemik di Danau Poso sebagai ikan pelagis dengan relung daerah bebatuan. Ikan rono tersebar di seluruh kawasan Danau Poso dan merupakan ikan yang digemari masyarakat dan menjadi makanan khas penduduk di sekitar danau. Ikan rono memiliki karakter dimorfisme seksual antara jantan dan betina yang merupakan adaptasi organ untuk alat bantu pemijahan (Rahardjo et al. 2010, Gundo et al. 2013). Terdapat paling tidak sembilan jenis ikan endemik di Danau Poso dengan status pada red list data book dari IUCN (2010) dalam tatanan konservasi mulai dari populasi rentan (vulnerable/ $\mathrm{VU})$, genting (endangered/EN), hingga kritis (critical rare/CR), bahkan satu jenis sudah dinyatakan punah (Rahardjo 2015).

Ikan rono memiliki karakter yang unik sebagai hasil adaptasi terhadap lingkungannya. Secara geografis Danau Poso berada di tengah Pulau Sulawesi, pada posisi antara $1^{\circ} 44^{\prime} 2^{\circ} 04^{\prime} \mathrm{LS}$ dan $120^{\circ} 32^{\prime}-120^{\circ} 43^{\prime}$ BT. Luasnya Danau Poso dan mikrohabitat khusus yang disukai ikan rono mengakibatkan penyebaran populasinya terkonsentrasi pada habitat spesifik (Gundo et al. 2013), membentuk meta populasi dan memungkinkan semakin kecilnya perkawinan acak antarmeta populasi (panmictic population). Kondisi demikian tidak memungkinkan aliran gen (gene flow) antargenerasi terjadi secara utuh. Akibatnya akan terjadi keragaman genetik diantara meta populasi. Keragaman genetik akibat kawin acak yang terbatas dan kemampuan adapatasi terhadap habitat akan memunculkan ekspresi gen dalam bentuk fenotipe yang berbeda antarlokasi atau habitat. Pengamatan keragaman fenotipe di antara populasi dan spesies merupakan cara memahami proses yang mengarah kepada diversifikasi spesies di dalam suatu ekosistem
(Schluter 2000). Rangkaian kejadian dalam proses tersebut berhubungan dengan keragaman fenotipe yang diperankan oleh gen dan konsekuensi dari sintasan suatu populasi. Selain itu keragaman dalam morfologi, tingkah laku atau siklus hidup merupakan kombinasi antara heterogenitas lingkungan ekstrim dan adaptasi dari gen kelenturan fenotipik (Robinson \& Parsons 2002).

Dalam hubungannya dengan kerentanan populasi ikan rono di Danau Poso, maka pemahaman keragaman morfometrik dapat digunakan sebagai pemahaman dalam melakukan konservasi ikan tersebut. Pemahaman tentang keragaman genetik dan dinamika populasi merupakan komponen penting dalam merancang strategi konservasi ikan endemik yang terbatas luas wilayahnya.

Tujuan penelitian ini adalah untuk mengevaluasi keragaman fenotipik dan genotipik ikan rono di Danau Poso, Sulawesi Tengah.

\section{Bahan dan metode}

Pengumpulan ikan contoh dilakukan pada tiga stasiun pengambilan contoh (Gambar 1). Stasiun pengambilan contoh satu (S-1) berada di bagian timur Danau Poso yaitu di perairan Desa Tolambo. Sebagian daratan merupakan daerah pertanian dan sebagian lagi merupakan daerah hutan berbatu. Kemiringan lereng daerah pantai sebagian besar tergolong curam, dan terdapat batu-batuan besar yang berbatasan langsung dengan perairan, didominasi oleh zona litoral yang sempit.

Stasiun pengambilan contoh dua (S-2) terletak di bagian barat Danau Poso yaitu di sekitar perairan Tando Taipa. Daerah ini merupakan wilayah Desa Taipa. Pantai berbentuk tanjung berbatu dengan zona litoral sempit. Daratan merupakan kawasan hutan dengan kemiringan lereng sebagian besar tergolong curam. Daerah daratan merupakan kawasan hutan berbatu dengan kemi- 
ringan lereng sangat curam. Pantai berbatu dan berpasir dengan daerah litoral yang sempit.

Stasiun tiga (S-3) merupakan perairan yang berdekatan dengan aliran air keluar (outlet) dari Danau Poso daerah Tentena. Stasiun ini terletak di bagian utara, yaitu di sepanjang pantai Tando Dilana, Watu Mpangasa, Tamuu, Tando Lala, Towale. Daratan merupakan daerah pertanian. Sebagian besar pantai tergolong curam terdapat batu-batuan berukuran besar yang berbatasan langsung dengan dasar perairan yang curam dan memiliki zona litoral yang sempit.

Sampel yang diambil dari ketiga lokasi tersebut selanjutnya diamati secara morfometrik dan molekuler. Secara morfometrik ikan dianalisis menggunakan truss morphometric (Gambar 2) dan secara molekuler dengan analisis sekuen- sing DNA. Populasi ikan rono yang diamati diambil dari tiga lokasi yang berbeda dan dalam analisis dibagi menjadi lima sampel: 1 . Tolambo dalam analisis diberi notasi: 1. Tolambo-Mata Besar (Tolambo-MB) dan 2. Tolambo-Mata Kecil (Tolambo-MK); 2. Taipa dalam analisis diberi notasi: 3. Taipa-Mata Kecil (Taipa-MK) dan 5. Taipa-Mata Besar (Taipa-MB); 3. Tentena (dalam analisis diberi notasi: 4 Tentema). Masingmasing sampel untuk analisis morfometrik sebanyak 30 ekor.

Analisis bentuk (shape analysis) dilakukan dengan membagi tubuh ikan menjadi titik-titik land mark dengan penghubung garis truss (truss line) menjadi bentuk yang khas untuk melihat perbedaan satu populasi dengan populasi lainnya.

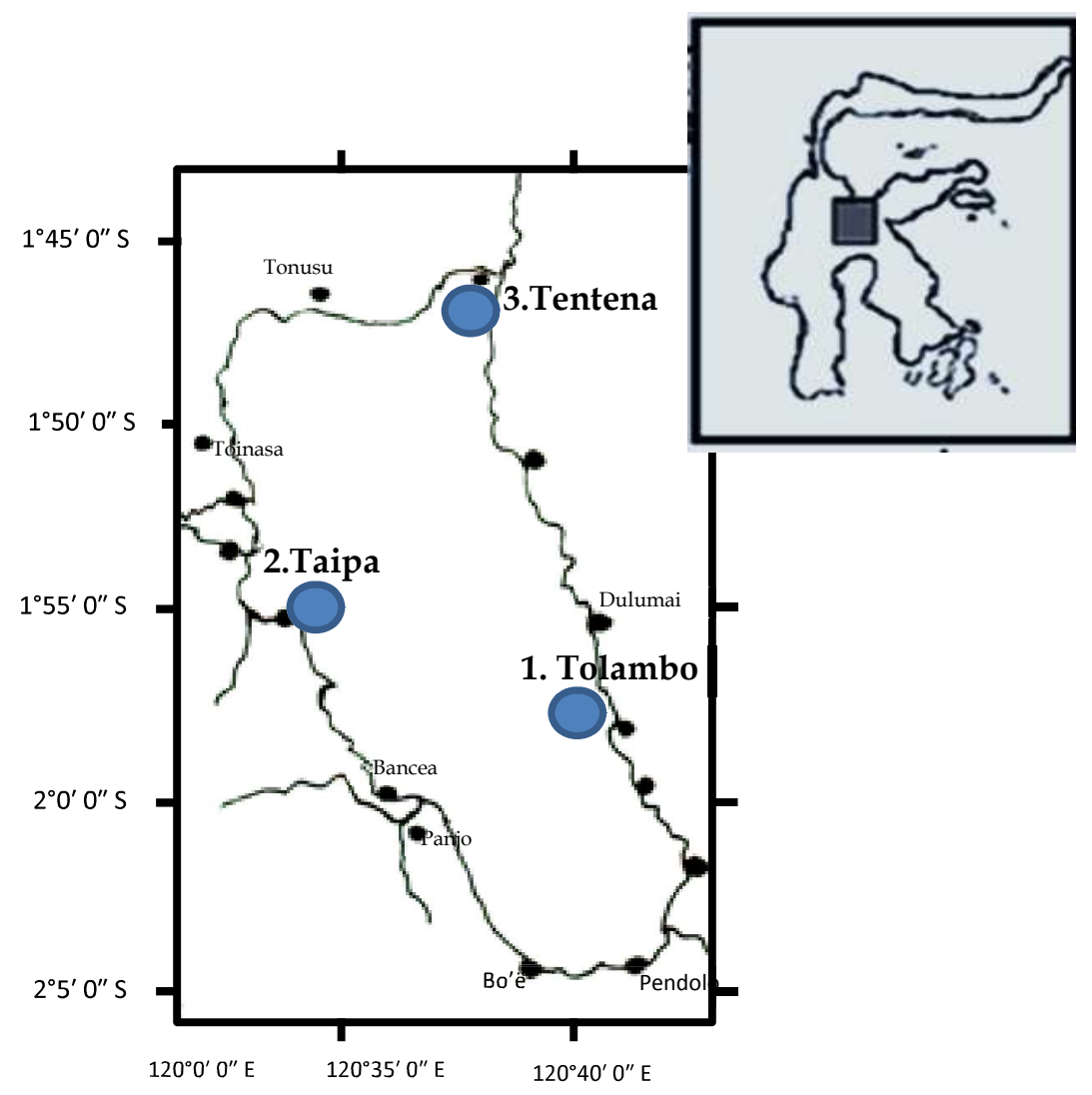

Gambar 1. Lokasi stasiun pengambilan contoh ikan rono di Danau Poso, untuk pengamatan morfometrik dan molekuler. 1. Tolambo; 2 Taipa; 3. Tentena. 


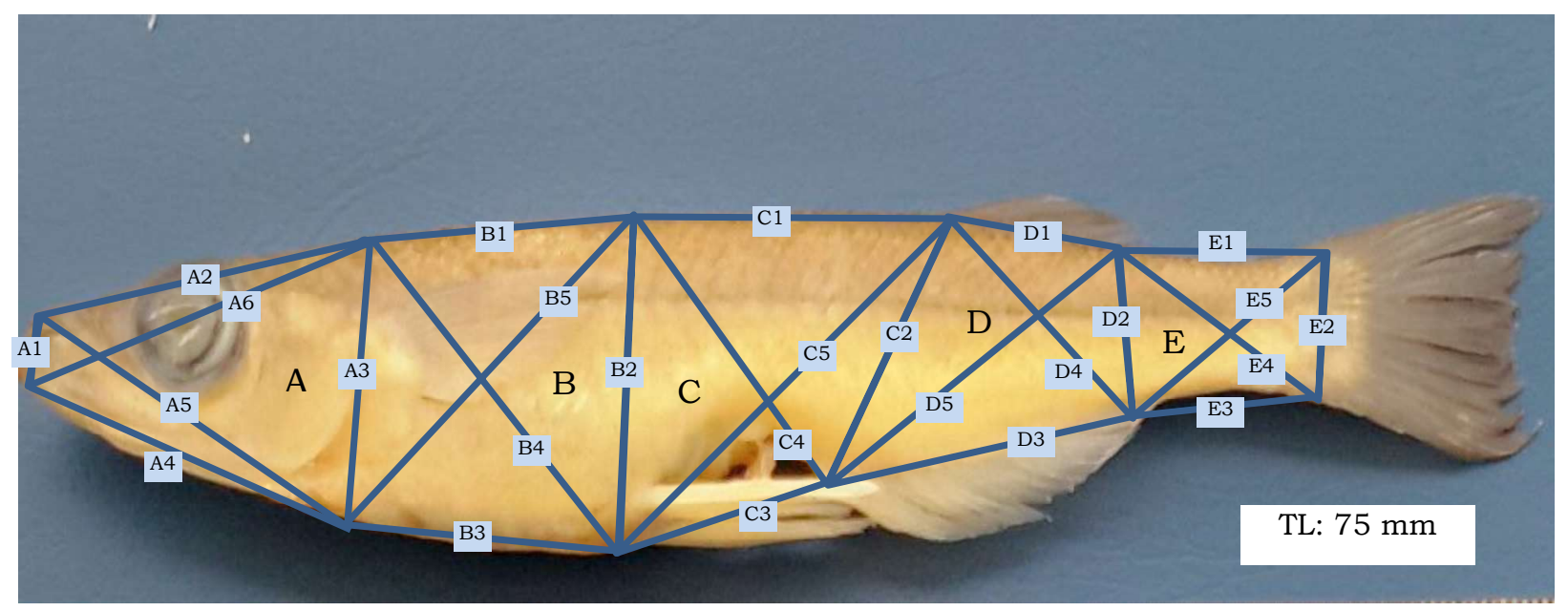

Gambar 1. Pembuatan truss morphometric dengan membagi tubuh ikan rono ke dalam truss cell dan garis truss. Badan ikan dibagi ke dalam lima truss cell (A,B,C, D dan E), Masing-masing truss cell dibagi kedalam garis truss (A1-E5).

\begin{tabular}{|c|c|c|}
\hline Kode & Garis truss & Karakter morfologi \\
\hline A1 & Tinggi moncong dari rahang bawah - rahang atas & $\begin{array}{l}\text { Lebar kepala } \\
\text { depan }\end{array}$ \\
\hline A2 & $\begin{array}{l}\text { Jarak anatara bagian depan moncong atas - titik vertico-dorsal operculum bagian } \\
\text { belakang }\end{array}$ & \\
\hline A3 & Tinggi kepala bagian belakang operculum & $\begin{array}{l}\text { Bagian kepala } \\
\text { terlebar }\end{array}$ \\
\hline A4 & Jarak antara titik vertico-ventral operculum belakang - titik ujung rahang bawah & \\
\hline A5 & $\begin{array}{l}\text { Diagonal antara titik vertico-ventral operculum belakang - ujung moncong bagian } \\
\text { atas }\end{array}$ & \\
\hline A6 & $\begin{array}{l}\text { Diagonal antara titik vertico-dorsal operculum bagian belakang - ujung moncong } \\
\text { bagian bawah }\end{array}$ & \\
\hline B1 & $\begin{array}{l}\text { Jarak antara titik vertico-dorsal operculum bagian belakang -titik vertico-dorsal } \\
\text { pangkal sirip perut }\end{array}$ & \\
\hline B2 & Jarak antara titik vertico-dorsal pangkal sirip perut - pangkal sirip perut & $\begin{array}{l}\text { Bagian badan } \\
\text { terlebar }\end{array}$ \\
\hline B3 & Jarak antara titik vertico-ventral operculum belakang - pangkal sirip perut & \\
\hline B4 & Diagonal pangkal sirip perut - titik vertico-dorsal operculum bagian belakang & \\
\hline B5 & $\begin{array}{l}\text { Diagonal titik vertico-ventral operculum belakang - titik vertico-dorsal pangkal } \\
\text { sirip perut }\end{array}$ & \\
\hline $\mathrm{C} 1$ & Jarak antara titik vertico-dorsal pangkal sirip perut - pangkal sirip punggung & \\
\hline $\mathrm{C} 2$ & Jarak antara pangkal sirip punggung - pangkal sirip anal & \\
\hline $\mathrm{C} 3$ & Jarak antara pangkal sirip anal - pangkal sirip perut & $\begin{array}{l}\text { Lebar ruang } \\
\text { pengeraman telur }\end{array}$ \\
\hline $\mathrm{C} 4$ & Diagonal antara pangkal sirip punggung - titik vertico-dorsal pangkal sirip perut & \\
\hline $\mathrm{C} 5$ & Diagonal antara pangkal sirip punggung - pangkal sirip perut & \\
\hline D1 & Jarak antara pangkal sirip punggung - bagian akhir sirip punggung & \\
\hline D2 & Jarak antara bagian akhir sirip punggung - bagian akhir sirip anal & $\begin{array}{l}\text { Lebar badan } \\
\text { bagian belakang }\end{array}$ \\
\hline D3 & Jarak antara bagian akhir sirip anal - bagian awal sirip anal & \\
\hline D4 & Diagonal bagian akhir sirip punggung - bagian awal sirip anal & \\
\hline D5 & Diagonal bagian awal sirip anal - bagian akhir sirip punggung & \\
\hline
\end{tabular}




\begin{tabular}{cll}
\hline Kode & \multicolumn{1}{c}{ Garis truss } & Karakter morfologi \\
\hline E1 & Jarak antara bagian akhir sirip punggung - pangkal sirip ekor bagian dorsal & \\
E2 & Jarak antara pangkal sirip ekor dorsal - pangkal sirip ekor ventral & \\
E3 & Jarak antara pangkal sirip ekor ventral - bagian akhir sirip anal & \\
E4 & Diagonal pangkal sirip ekor ventral - bagian akhir sirip punggung & \\
E5 & Diagonal antara bagian akhir sirip anal - pangkal sirip ekor bagian dorsal & \\
\hline
\end{tabular}

Data ukuran garis truss dianalisis menggunakan statistic program SAS .6.12 dan SPSS V.21. Analisis dikriminan dilakukan dengan menggunakan prinsip fungsi diskriminan linear dengan validasi silang antara fungsi jarak kuadrat dengan probabilitas bagian akhir dari keanggotaan masing-masing lokasi (SAS 1997) dengan rumus:

$$
\begin{aligned}
D_{j}^{2}(X) & =\left(X-\bar{X}_{(X) j}\right)^{\prime} \operatorname{Cov}_{(X)}^{-1}\left(X-\bar{X}_{(X) j}\right) \\
\operatorname{Pr}_{(j / x)} & =\operatorname{Exp} \frac{\left(-0,5 D_{j}^{2}(X)\right)}{\operatorname{Sum}_{k} \exp \left(-0,5 D_{k}^{2}(X)\right)}
\end{aligned}
$$

Keterangan:

$D_{(i / j)}^{2}=$ nilai statistik mahalobis sebagai ukuran jarak kuadrat genetik antar populasi;

$\mathrm{Cov}^{-1}=$ kebalikan matrik gabungan ragam peragam antar peubah;

$\bar{X}_{i}=$ vektor nilai rataan pengamatan dari populasi I pada masing-masing peubah;

$\bar{X}_{j}=$ vektor nilai rataan pengamatan dari populasi j pada masing-masing peubah;

$\operatorname{Pr}\left(\frac{j}{X}\right)=$ probabilitas;

$\operatorname{Exp}=$ perkiraan.

Untuk menganalisis mahalanobis digunakan program SAS V.6.12 dengan menggunakan PROC DISCRIM (Suparyanto et al. 1999). Jarak kuadrat yang didapatkan kemudian diakarkan. Peta penyebaran populasi dan nilai kesamaan di dalam dan di luar kelompok didapatkan dengan menggunakan analisis diskriminan yaitu analisis komponen utama (principle component analysis). Komponen ini juga digunakan untuk melihat pengaruh yang paling kuat terhadap pembentukan populasi utama. Untuk memperkecil variasi ukuran, maka semua variabel trus dibakukan dengan panjang totalnya masing-masing.
Analisis DNA dilakukan sebagai konfirmasi terhadap keragaan fenotipe yang terekspresi sebagai hasil adaptasi habitat yang berbeda. Untuk keperluan tersebut analisis dilakukan hingga taraf sekuensi DNA. Tahapan analisis DNA meliputi ekstraksi, amplifikasi polymerase chain reaction (PCR), visualisasi pita DNA, perunutan nukleotida, dan analisis data hasil sekuensing.

Ekstraksi DNA dilakukan terhadap sampel ikan asal organ sirip pectoral yang dipreservasi dalam etanol 70\%. Ekstraksi dilakukan menggunakan kit DNeasy minikit (Qiagen) dengan mengacu pada prosedur yang ditentukan oleh perusahaan tersebut. Amplifikasi PCR dilakukan terhadap target gen pada segmen DNA mitokondria bagian gen COI. Amplifikasi dilakukan menggunakan teknik PCR dengan mesin thermo cycler Applied Biosystem PE9700. Primer yang digunakan adalah Fish1F:

5'TCAACCAACCACAAAGACATTGGCAC-3' dan Fish1R:

\section{5'-TAGACTTCTGGGTGGCCAAAGAATCA-3'}

yang akan menghasilkan produk PCR sekitar 650 bp (Ward et al. 2005). Volume total PCR adalah $25 \mu \mathrm{l}$ yang mengandung $1 \mu \mathrm{l}$ masing-masing primer, 12,5 $\mu 1$ KAPA hot start ready mix (KAPA), 5,5 $\mu 1$ nuclease free water dan $5 \mu \mathrm{DNA}$ sampel. Proses amplifikasi dalam mesin PCR meliputi: denaturasi $94^{\circ} \mathrm{C}$ selama 5 menit sebagai PrePCR, $94^{\circ} \mathrm{C}$ selama 30 detik untuk proses denaturasi, $52^{\circ} \mathrm{C}$ selama 30 detik untuk proses annealing, $72^{\circ} \mathrm{C}$ selama 30 detik untuk proses extention. Proses tersebut diulang selama 40 kali dan 
diakhiri dengan proses post extention pada suhu $72^{\circ} \mathrm{C}$ selama 7 menit dan ditahan pada suhu $4^{\circ} \mathrm{C}$.

Produk PCR selanjutnya dijalankan dalam elekroforesis agarose 1,8\% dalam bufer TAE dengan menggunakan ethidium bromide sebagai pewarna DNA. Elektroforesis dijalankan menggunakan tegangan $100 \mathrm{~V}$ selama 45 menit. Produk PCR hasil elektroforesis selanjutnya divisualisasi menggunakan sinar ultraviolet dalam alat GelDoc (BioRad).

Produk PCR dengan ukuran pita sekitar 650 bp selanjutnya dikirim ke $1^{\text {st }}$ Base Malaysia untuk ditentukan runutan nukleotidanya. Primer yang digunakan untuk proses sekuensing adalah sama dengan primer yang digunakan untuk proses amplifikasi PCR. Urutan basa nukleotida hasil sekuensing akan divisualisasi ektrogram dan urutan basa nukleotidanya menggunakan software BioEdit, ClustalW dan MEGA5. Hasil sekuensing selanjutnya disejajarkan (alignment) menggunakan perangkat program BLAST (basic local align search tool) dari NCBI (National Center for Biotechnology Information).

\section{Hasil}

Keragaan morfologi

Keragaan karakter morfometrik yang merupakan rataan garis truss (truss line) hasil pengukuran yang telah disetarakan dengan panjang total yakni dengan membagi garis truss dengan panjang total dapat dilihat pada Tabel 1. Ukuran karakter ini memberikan gambaran keragaman ukuran penyusun bentuk tubuh ikan masingmasing lokasi sampel. Hasil rataan komponen karakter tersebut dapat digunakan untuk menyusun bentuk bangun tubuh yang berbeda antarlokasi.

Rataan keragaan morfometrik berdasarkan hasil analisis diskriminan menunjukkan adanya perbedaan bentuk antarlokasi sampel (Gambar 2). Hasil analisis dengan menggunakan prosedur analisis komponen utama memperlihatkan adanya penyebaran teritorial populasi yang berbeda berdasar komponen utama karakter garis truss.

Tabel 1. Rataan variabel ukuran garis truss yang terbakukan dengan panjang total masing-masing dari lima populasi sampel ikan rono di Danau Poso

\begin{tabular}{cccccc}
\hline \multirow{2}{*}{ KODE } & $\begin{array}{c}1 \\
\text { Tolambo-MB }\end{array}$ & $\begin{array}{c}2 \\
\text { Tolambo-MK }\end{array}$ & $\begin{array}{c}3 \\
\text { Taipa-MK }\end{array}$ & $\begin{array}{c}4 \\
\text { Tentena }\end{array}$ & $\begin{array}{c}5 \\
\text { Taipa-MB }\end{array}$ \\
\hline A1 & 0,23 & 0,05 & 0,07 & 0,06 & 0,07 \\
A2 & 0,23 & 0,25 & 0,24 & 0,22 & 0,23 \\
A3 & 0,19 & 0,19 & 0,18 & 0,19 & 0,18 \\
A4 & 0,24 & 0,26 & 0,24 & 0,23 & 0,25 \\
A5 & 0,26 & 0,27 & 0,26 & 0,24 & 0,27 \\
A6 & 0,25 & 0,26 & 0,25 & 0,25 & 0,25 \\
B1 & 0,22 & 0,22 & 0,20 & 0,22 & 0,20 \\
B2 & 0,22 & 0,22 & 0,21 & 0,22 & 0,23 \\
B4 & 0,22 & 0,21 & 0,22 & 0,23 & 0,20 \\
B5 & 0,30 & 0,30 & 0,29 & 0,30 & 0,28 \\
B6 & 0,30 & 0,30 & 0,28 & 0,31 & 0,28 \\
\hline
\end{tabular}


Tabel 1 (lanjutan). Rataan variabel ukuran garis truss yang terbakukan dengan panjang total masingmasing dari lima populasi sampel ikan rono di Danau Poso

\begin{tabular}{cccccc}
\hline \multirow{2}{*}{ KODE } & 1 & 2 & 3 & 4 & 5 \\
& Tolambo-MB & Tolambo-MK & Taipa-MK & $\begin{array}{c}\text { Tentena } \\
\text { Taipa-MB }\end{array}$ \\
\hline C1 & 0,23 & 0,22 & 0,24 & 0,25 & 0,24 \\
C2 & 0,21 & 0,22 & 0,21 & 0,21 & 0,23 \\
C4 & 0,13 & 0,14 & 0,14 & 0,12 & 0,15 \\
C5 & 0,23 & 0,24 & 0,23 & 0,23 & 0,25 \\
C6 & 0,31 & 0,31 & 0,31 & 0,31 & 0,33 \\
D1 & 0,17 & 0,19 & 0,17 & 0,17 & 0,17 \\
D2 & 0,13 & 0,13 & 0,15 & 0,13 & 0,14 \\
D4 & 0,26 & 0,27 & 0,20 & 0,26 & 0,26 \\
D5 & 0,22 & 0,24 & 0,20 & 0,23 & 0,23 \\
D6 & 0,30 & 0,31 & 0,28 & 0,31 & 0,31 \\
E1 & 0,16 & 0,14 & 0,17 & 0,15 & 0,16 \\
E2 & 0,12 & 0,12 & 0,12 & 0,12 & 0,11 \\
E4 & 0,16 & 0,13 & 0,18 & 0,12 & 0,15 \\
E5 & 0,20 & 0,18 & 0,19 & 0,18 & 0,19 \\
E6 & 0,20 & 0,17 & 0,20 & 0,18 & 0,19 \\
\hline
\end{tabular}

Keterangan: $\mathrm{n}(1,2,3,4,5)=30$ ekor

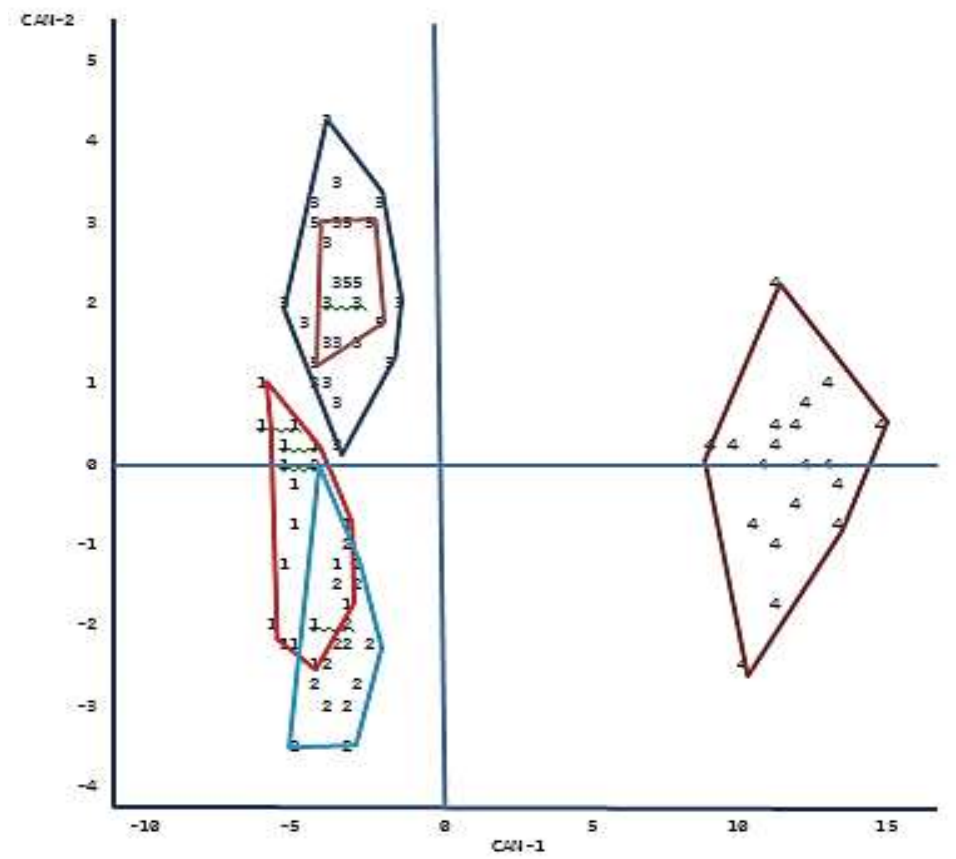

Gambar 2. Distribusi komponen morfometrik dari lima populasi ikan rono di Danau Poso menggunakan anilisis komponen utama. 1. Tolambo-MB, 2. Tolambo-MK, 3. Taipa-MK, 4. Tentena dan 5. Taipa-MB. 
Nilai uji keragaman karakter garis truss untuk menunjukkan arah perbedaan bentuk bangun tubuh secara menyeluruh (Tabel 2). Analisis 26 karakter untuk melihat perbedaan bentuk tubuh antarlokasi menunjukkan bahwa 12 karakter tidak berbeda (ns); 3 berbeda nyata $\left(^{*}\right)$; dan 11 berbeda sangat nyata $(* *)$.

Nilai percampuran komponen (sharing component) antarpopulasi dari tiga lokasi yang berbeda (Tabel 3) menunjukkan adanya pertautan genetik (sharing allele) antarpopulasi yang menunjukkan seberapa besar andilnya dalam mem- bentuk karakter dasar dari jenis tersebut kepada seluruh populasi yang ada. Setiap populasi akan memiliki karakter yang membangun membentuk tubuh secara utuh $100 \%$.

Hasil analisis klaster dengan menggunakan jarak euklidean (euclidean distance) sebagai jarak matrik memperlihatkan kaitan antarpopulasi berdasarkan ukuran truss morphometric dapat dilihat pada Gambar 3. Gambar tersebut menunjukkan kaitan antarpopulasi dari masing-masing lokasi sampel.

Tabel 2. Hasil uji keragaman karakter garis truss yang menunjukkan arah perbedaan bentuk badan secara simultan pada ketiga lokasi sampel

\begin{tabular}{|c|c|c|c|}
\hline Karakter & Wilks' Lambda & $\mathrm{F}$ & Sig. \\
\hline A1 & 0,032 & 625,389 & $0,000 * *$ \\
\hline $\mathrm{A} 2$ & 0,857 & 3,465 & 0,011 * \\
\hline $\mathrm{A} 3$ & 0,977 & 1,478 & $0,752^{\mathrm{ns}}$ \\
\hline A4 & 0,825 & 4,391 & $0,003 * *$ \\
\hline A5 & 0,846 & 3,772 & $0,007 * *$ \\
\hline A6 & 0,946 & 1,184 & $0,324^{\mathrm{ns}}$ \\
\hline B1 & 0,925 & 1,690 & $0,160^{\mathrm{ns}}$ \\
\hline B2 & 0,952 & 1,050 & $0,386^{\mathrm{ns}}$ \\
\hline B4 & 0,894 & 2,468 & $0,051^{\mathrm{ns}}$ \\
\hline B5 & 0,916 & 1,897 & $0,119^{\mathrm{ns}}$ \\
\hline B6 & 0,803 & 5,083 & $0,001 * *$ \\
\hline $\mathrm{C} 1$ & 0,922 & 1,758 & $0,145^{\mathrm{ns}}$ \\
\hline $\mathrm{C} 2$ & 0,805 & 5,032 & $0,001 * *$ \\
\hline $\mathrm{C} 4$ & 0,911 & 2,016 & $0,100^{\mathrm{ns}}$ \\
\hline $\mathrm{C} 5$ & 0,931 & 1,541 & $0,198^{\mathrm{ns}}$ \\
\hline C6 & 0,903 & 2,226 & $0,073^{\mathrm{ns}}$ \\
\hline D1 & 0,873 & 3,009 & $0,023^{*}$ \\
\hline D2 & 0,898 & 2,362 & $0,060^{\mathrm{ns}}$ \\
\hline D4 & 0,734 & 7,537 & $0,000 * *$ \\
\hline D5 & 0,827 & 4,354 & $0,003 * *$ \\
\hline D6 & 0,890 & 2,567 & $0,044 *$ \\
\hline E1 & 0,805 & 5,014 & $0,001 * *$ \\
\hline E2 & 0,917 & 1,884 & $0,121^{\mathrm{ns}}$ \\
\hline $\mathrm{E} 4$ & 0,696 & 9,058 & $0,000 * *$ \\
\hline E5 & 0,837 & 4,034 & $0,005^{* *}$ \\
\hline E6 & 0,842 & 3,906 & $0,006 * *$ \\
\hline
\end{tabular}

Keterangan: ns: tidak berbeda; *: Berbeda nyata; **: berbeda sangat nyata 


\section{Keragaan molekuler}

Hasil pemindaian DNA melalui amplifikasi PCR lima sampel (1. Tolambo-MB, 2. Tolambo-

MK, 3. Taipa-MK, 4. Tentena, 5. Taipa-MB) da- ri tiga populasi (Tolambo, Taipa, dan Tentena) menunjukkan adanya keragaman kecil seperti terlihat pada Gambar 4.

Tabel 3. Nilai percampuran fenotipe morfometrik dalam dan antar poulasi (\%) yang menunjukkan andil gen (sharing component) berdasarkan analisis dikriminan

\begin{tabular}{lcccccc}
\hline \multicolumn{1}{c}{ Lokasi } & Tolambo-MB & Tolambo-MK & Taipa-MK & Tentena & Taipa-MB & Total \\
\hline Tolambo-MB & 55 & 35 & 10 & 0 & 0 & 100 \\
Tolambo-MK & 10 & 80 & 10 & 0 & 0 & 100 \\
Taipa-MK & 30 & 10 & 45 & 0 & 15 & 100 \\
Tentena & 0 & 0 & 0 & 100 & 0 & 100 \\
Taipa-MB & 12,5 & 0 & 50 & 0 & 37,5 & 100 \\
\hline
\end{tabular}

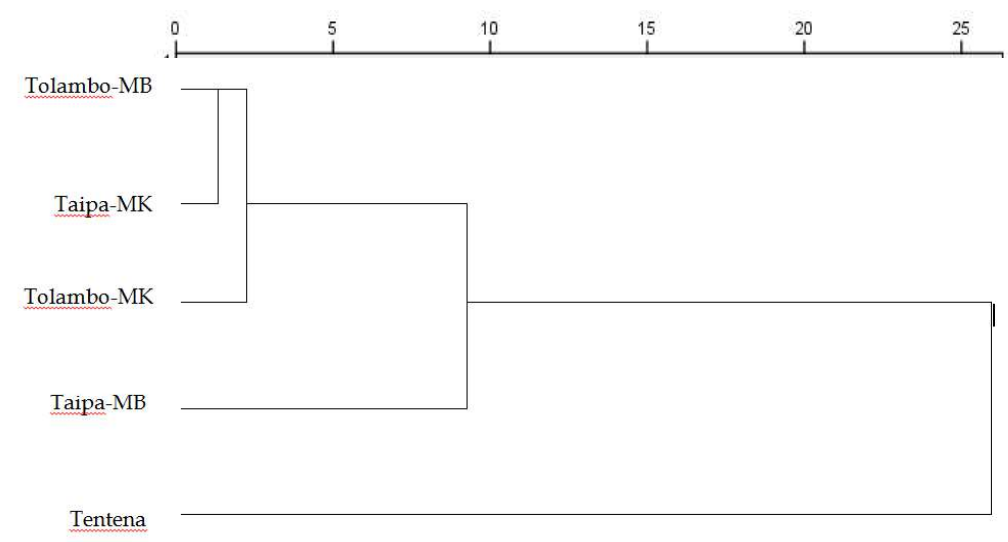

Gambar 3. Dendrogram jarak genetik antarpopulasi ikan rono di Danau Poso dengan menggunakan analisis cluster euclidean distance dari rataan karakter antarpopulasi ikan rono di Danau Poso. Keterangan: Tolambo-MB: Tolambo Mata Besar; Tolambo-MK: Tolambo Mata Kecil; TaipaMK: Taipa Mata Kecil; Taipa-MB: Taipa Mata Besar.

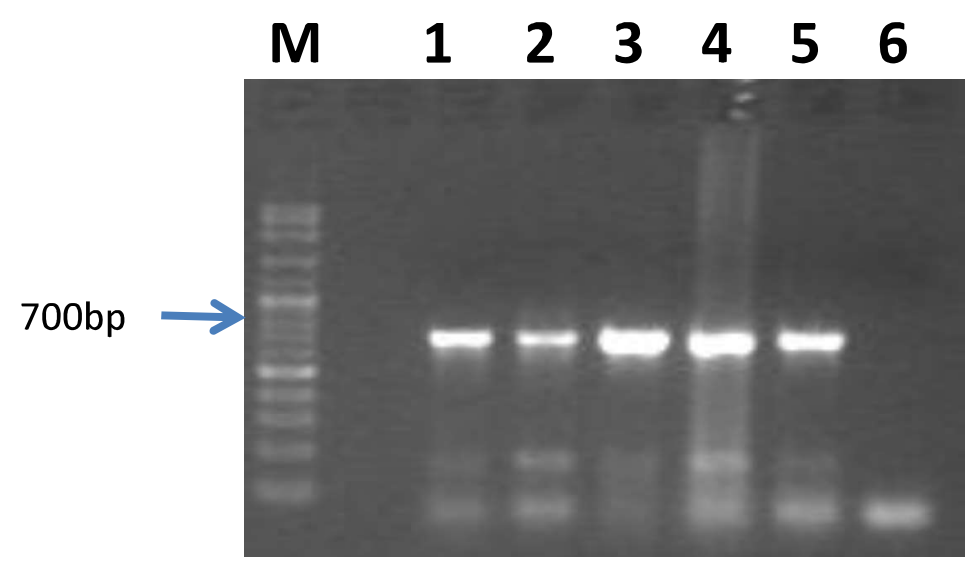

Gambar 4. Hasil pemindaian DNA sampel ikan rono dari tiga populasi yang berbeda. M. Ladder 100bp (Vivantis). 1. Tolambo-MB, 2. Tolambo-MK, 3. Taipa-MK, 4. Tentena, 5. Taipa-MB, 6. Kontrol negatif. 
Dari hasil analisis sekuensing DNA dihasilkan urutan nukleotida hasil perunutan nukleotida antar lima sampel berbeda yang berasal dari tiga populasi yang dilakukan di First Base, Ltd Ma- laysia. Dari hasil tersebut selanjutnya dibuat penyejajaran nukleotida (alignment) dengan metode Clustal Wallis seperti terlihat pada Gambar 5.
4. Tentena
5. Taipa-MB
3. Taipa-MK
1. Tolambo-MB
2. Tolambo-MK
4. Tentena
5. Taipa-MB
3. Taipa-MK
1. Tolambo-MB
2. Tolambo-MK

\section{Tentena 5. Taipa-MB 3. Taipa-MK 1. Tolambo-MB \\ 2. Tolambo}

4. Taipa-MB

5. Tentena

3. Taipa-MK

1. Tolambo-MB

2. Tolambo-MK
4. Tentena
5. Taipa-MB
3. Taipa-MK
1. Tolambo-MB
2. Tolambo-MK

4. Tentena

5. Taipa-MB

3. Taipa-MK

1. Tolambo-MB

2. Tolambo-MK

\section{Tentena \\ 5. Taipa-MB \\ 3. Taipa-MK \\ 1. Tolambo-MB \\ 2. Tolambo-MK}
4. Tentena
5. Taipa-MB
3. Taipa-MK
1. Tolambo-MB
2. Tolambo-MK

4. Tentena

5. Taipa-MB

3. Taipa-MK
TAGTTGGCACCGCTCTAAGCCTACTCATCCGAGCGGAACTAAGCCAGCCTGGCTCTTTGC TAGTTGGCACCGCTCTAAGCCTACTCATCCGAGCGGAACTAAGCCAGCCTGGCTCTTTGC TAGTTGGCACCGCTCTAAGCCTACTCATCCGAGCGGAACTAAGCCAGCCTGGCTCTTTGC TAGTTGGCACCGCTCTAAGCCTACTCATCCGAGCGGAACTAAGCCAGCCTGGCTCTTTGC TAGTGGGCACCGCTCTAAGTCTACTCATCCGGGCAGAACTAAGCCAGCCTGGCTCTTTAC

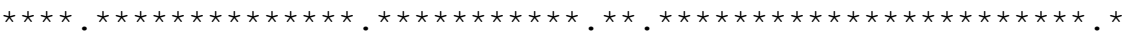

TAGTTGGCACCGCTCTAAGCCTACTCATCCGAGCGGAACTAAGCCAGCCTGGCTCTTTGC TAGTTGGCACCGCTCTAAGCCTACTCATCCGAGCGGAACTAAGCCAGCCTGGCTCTTTGC TAGTTGGCACCGCTCTAAGCCTACTCATCCGAGCGGAACTAAGCCAGCCTGGCTCTTTGC TAGTTGGCACCGCTCTAAGCCTACTCATCCGAGCGGAACTAAGCCAGCCTGGCTCTTTGC TAGTGGGCACCGCTCTAAGTCTACTCATCCGGGCAGAACTAAGCCAGCCTGGCTCTTTAC

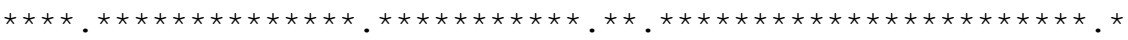

TGGGTGACGACCAGATTTACAACGTGATCGTCACTGCACATGCCTTTGTTATAATCTTTT TGGGTGACGACCAGATTTACAACGTGATCGTCACTGCACATGCCTTTGTTATAATCTTTT TGGGTGACGACCAGATTTACAACGTGATCGTCACTGCACATGCCTTTGTTATAATCTTTT TGGGTGACGACCAGATTTACAACGTGATCGTCACTGCACATGCCTTTGTTATAATCTTTT TGGGCGACGACCAGATCTATAACGTGATCGTCACAGCACATGCCTTCGTCATAATCTTTT

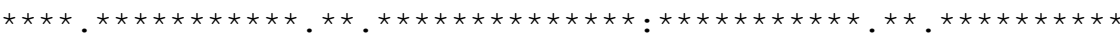

TTATAGTAATGCCAATTATAATCGGAGGCTTTGGGAACTGACTGATTCCGTTGATGCTCG TTATAGTAATGCCAATTATAATCGGAGGCTTTGGGAACTGACTGATTCCGTTGATGCTCG TTATAGTAATGCCAATTATAATCGGAGGCTTTGGGAACTGACTGATTCCGTTGATGCTCG TTATAGTAATGCCAATTATAATCGGAGGCTTTGGGAACTGACTGATTCCGTTGATGCTCG TTATAGTAATGCCAATTATAATTGGAGGCTTTGGCAACTGACTGGTTCCGTTAATGCTCG

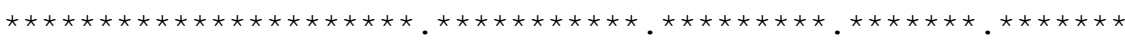

GCGCCCCCGACATAGCATTTCCTCGGATGAATAACATAAGCTTTTGACTTCTGCCCCCTT GCGCCCCCGACATAGCATTTCCTCGGATGAATAACATAAGCTTTTGACTTCTGCCCCCTT GCGCCCCCGACATAGCATTTCCTCGGATGAATAACATAAGCTTTTGACTTCTGCCCCCTT GCGCCCCCGACATAGCATTTCCTCGGATGAATAACATAAGCTTTTGACTTCTGCCCCCTT GCGCACCAGACATAGCATTTCCTCGGATAAATAACATAAGCTTTTGACTCCTGCCCCCTT

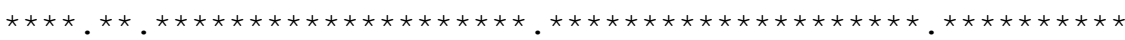

сстттсттсттстттяGстTCстCCGGAGTAGAAGCAGGGGCGGGTACGGGGTGAACAG сстттсттсттсттTTGGCTTCCTCCGGAGTAGAAGCAGGGGCGGGTACGGGGTGAACAG СстTтсттстTстTтTGGCTTCCTCCGGAGTAGAAGCAGGGGCGGGTACGGGGTGAACAG сстттсттсттсттTтGGCTTCCTCCGGAGTAGAAGCAGGGGCGGGTACGGGGTGAACAG CCTTTCTTCTTCTTTTGGTTCGTCAGGAGTAGAGGCGGGGGCAGGCACGGGGTGAACAG

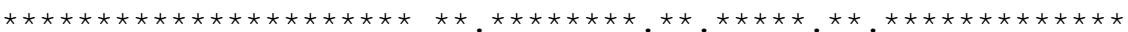

TATATCCCCCGCTGTCAGGCAACCTGGCCCATGCTGGGGCATCCGTGGACCTGACAATCT TATATCCCCCGCTGTCAGGCAACCTGGCCCATGCTGGGGCATCCGTGGACCTGACAATCT TATATCCCCCGCTGTCAGGCAACCTGGCCCATGCTGGGGCATCCGTGGACCTGACAATCT TATATCCCCCGCTGTCAGGCAACCTGGCCCATGCTGGGGCATCCGTGGACCTGACAATCT TGTACCCCCCTCTGTCTGGTAACCTGGCCCATGCTGGGGCATCCGTGGACCTAACAATCT

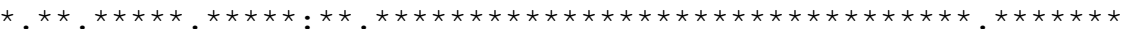

TCTCCCTTCATCTTGCCGGTGTCTCCTCTATCCTAGGGGCTATTAATTTTATTACCACAA TCTCCCTTCATCTTGCCGGTGTCTCCTCTATCCTAGGGGCTATTAATTTTATTACCACAA TCTCCCTTCATCTTGCCGGTGTCTCCTCTATCCTAGGGGCTATTAATTTTATTACCACAA тстCсCтTCATCTTGCCGGTGTCTCCTCTATCCTAGGGGCTATTAATTTTATTACCACAA TCTCCCTCCATCTTGCCGGGGTTTCATCTATCCTGGGGGCCATTAATTTTATTACCACGA

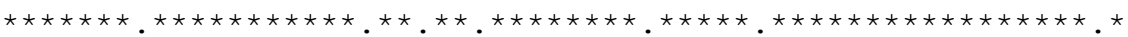

TTATTAACATAAAACCCCCTGCTATTTCTCAGTACCAGACGCCCCTCTTCGTCTGGTCTG TTATTAACATAAAACCCCCTGCTATTTCTCAGTACCAGACGCCCCTCTTCGTCTGGTCTG TTATTAACATAAAACCCCCTGCTATTTCTCAGTACCAGACGCCCCTCTTCGTCTGGTCTG 
1. Tolambo-MB

2. Tolambo-MK

4. Tentena

5. Taipa-MB

3. Taipa-MK

1. Tol ambo-MB

2. Tolambo-MK

4. Tentena

5. Taipa-MB

3. Taipa-MK

1. Tolambo-MB

2. Tolambo-MK
TTATTAACATAAAACCCCCTGCTATTTCTCAGTACCAGACGCCCCTCTTCGTCTGGTCTG TTATTAATATAAAACCCCCTGCTATCTCCCAGTACCAGACGCCCCTTTTCGTCTGGTCTG

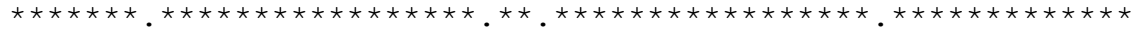

TGTTAATTACCGCCGTTTTACTCCTTCTTTCCCTTCCGGTGTTGGCCGCGGGAATCACCA TGTTAATTACCGCCGTTTTACTCCTTCTTTCCCTTCCGGTGTTGGCCGCGGGAATCACCA TATTAATTACCGCCGTTTTACTCCTTCTTTCCCTTCCGGTGTTGGCCGCGGGAATCACCA TGTTAATTACCGCCGTTTTACTCCTTCTTTCCCTTCCGGTGTTGGCCGCGGGAATCACCA TATTAATTACCGCCGTCTTACTCCTTCTATCCCTTCCGGTGTTGGCCGCGGGAATTACCA

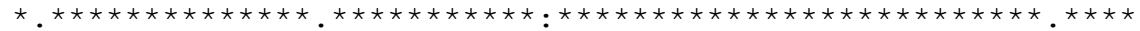

TGCTCCTAACAGACCGTAATTTAAACACAACATTCTTCGACCCGGCTGGCGGGGGG TGCTCCTAACAGACCGTAATTTAAACACAACATTCTTCGACCCGGCTGGCGGGGGG TGCTCCTAACAGACCGTAATTTAAACACAACATTCTTCGACCCGGCTGGCGGGGGG TGCTCCTAACAGACCGTAATTTAAACACAACATTCTTCGACCCGGCTGGCGGGGGG TGCTCCTAACAGACCGTAATTTGAACACAACATTCTTCGACCCGGCTGGCGGGGGG

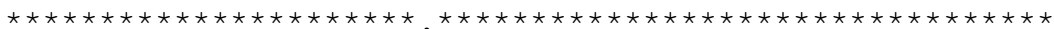

Gambar 5. Penyejajaran nukleotida (alignment) dengan metoda Clustal Wallis hasil analisa sekuens DNA ikan rono dari sampel Tolambo-MK; Tolambo-MB; Taipa-MK; Tentena; dan Taipa-MB

Matriks hubungan kedekatan antarsampel populasi berdasar hasil sekuensing DNA yang menunjukkan sharing allele dari sampel populasi yang berbeda terlihat pada Tabel 4. Tabel ini memberi gambaran bahwa kedekatan antarpopulasi dapat dipertanggungjawabkan secara genetik dengan adanya ekspresi DNA. Semakin tinggi nilai hubungan antara dua populasi menunjukkan semakin tinggi persamaan persamaan produk gen yang dikontrol oleh gen yang sama.

Hasil analisis sekuensing nukleotida setelah mengalami perunutan dan penyejajaran (alignment) juga menunjukkan keeratan hubungan yang berbeda antarpopulasi (Gambar 6).

Tabel 4. Matrik identitas tingkat homologi sekuen COI (\%) hasil sekuensi DNA yang menunjukkan keeratan hubungan antar populasi ikan rono di Danau Poso

\begin{tabular}{lccccc}
\hline & Tolambo-MB & Taipa-MK & Taipa-MB & Tentena & Tolambo-MK \\
\hline Tolambo -MB & - & & & & \\
Taipa-MK & 99,83 & - & & & \\
Taipa MB & 100 & 99,83 & - & & \\
Tentena & 100 & 99,83 & 100 & - & \\
Tolambo-MK & 92.11 & 92,28 & 92,11 & 92,11 & - \\
\hline
\end{tabular}

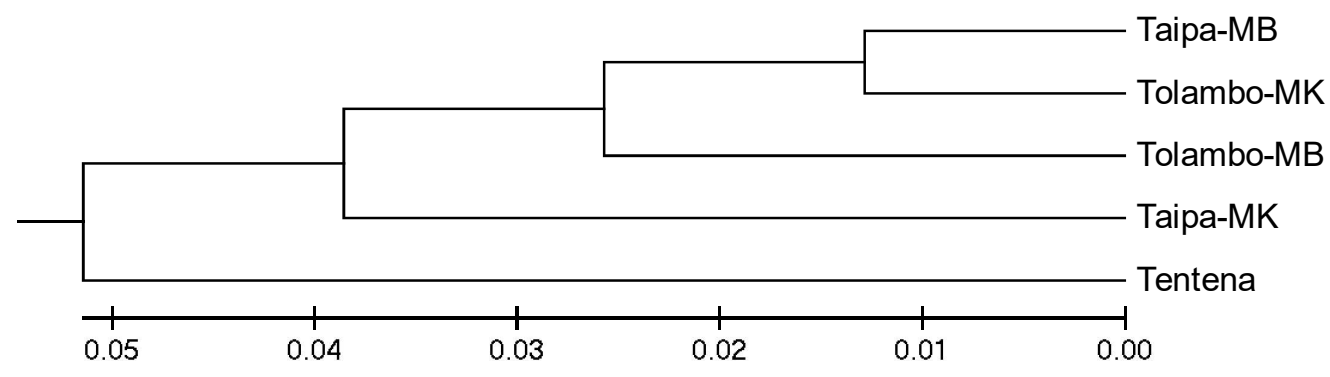

Gambar 6. Dendrogram berdasarkan hasil sekuensing DNA dari lima sampel pada tiga populasi yang berbeda yang menunjukkan hubungan kedekatan gen antarpopulasi 


\section{Pembahasan}

Keragaman morfometrik ikan rono membentuk dua kelompok yang berbeda secara nyata di antara populasi yang diamati. Pada Gambar 2 terlihat adanya pemisahan teritorial antarpopulasi menjadi dua kelompok besar yang terpisah. Kelompok satu yang berada pada kuadran satu dan kuadran empat yang meliputi empat sampel yaitu populasi-3 (Taipa-MK), populasi-5 (TaipaMB), populasi-1 (Tolambo-MB) dan populasi -2 (Tolambo-MK). Pada kelompok dua berada pada kuadran 2 dan 3 meliputi populasi-4 (Tentena). Secara morfometrik bangun tubuh ikan rono populasi Tentena memiliki beberapa perbedaan yang signifikan dibanding dengan populasi Taipa dan Tolambo sehingga terpisah.

Perbedaan bentuk secara morfologi dan juga secara molekuler tersebut mengindikasikan adanya adaptasi habitat yang memberi kesan adanya aktivitas gen kelenturan fenotipik yang bekerja pada masing-masing kelompok terutama pada populasi Tentena. Hasil analisis karakter dapat dikelompokkan kedalam tiga karakter yang berbeda.

Kelompok pertama merupakan karakter dasar semua populasi yang mencakup 12 karakter $(46,15 \%)$ yaitu semua karakter yang tidak berbeda (ns). Semua karakter dalam kelompok ini akan menjadi bentuk dasar ketiga populasi yang dianalisis.

Kelompok kedua adalah meliputi semua karakter ketiga lokasi yang berbeda $\left(^{*}\right)$ yang meliputi 3 karakter (11,54\%). Karakter yang masuk dalam kelompok ini merupakan karakter yang perubahannya belum terlalu permanen dan kemungkinan masih akan berubah sesuai dengan kondisi ruang dan waktu.

Kelompok ketiga adalah karakter yang berbeda sangat nyata $(* *)$ yang meliputi 11 karakter truss $(42,31 \%)$ dan akan menjadi penciri bentuk khusus populasi sebagai hasil adaptasi terhadap lingkungan tertentu.

Menurut Kirkpatrick \& Selander (1979) dan Stauffer \& Gray (2004), perbedaan bentuk tubuh adalah hasil revolusi sedikit gen yang berhubungan dengan lingkungan setempat dan bentuk aksi gen kelenturan fenotipik yang belum merupakan kanalisasi ataupun spesiasi. Dengan demikian perbedaan bentuk bangun tubuh yang terjadi pada populasi Tentena dengan populasi lain belum mengarah pada perbedaan spesies.

Komponen truss yang membangun bentuk tubuh tersebut dapat memiliki nilai yang sama dengan karakter pada populasi lain (ns) sehingga membentuk bangun tubuh secara utuh, kejadian ini disebut sharing component atau sharing allele. Komponen yang berupa jaringan ataupun organ yang akan memberikan bentuk tubuh yang khas masing-masing populasi adalah ekspresi sifat genetik yang diperankan oleh alel. Dari masing-masing populasi dapat dilihat sharing component kepada populasi lain.

Rataan karakter seperti pada Tabel 1, karena ukuran garis truss sudah terkoreksi dengan panjang total, keragaman ukuran sampel tidak memengaruhi bentuk bangun tubuh dasar masingmasing populasi. Karakter tersebut secara keseluruhan akan membentuk bangun tubuh ikan yang berbeda-beda antarpopulasi sesuai dengan kemampuan adaptasi terhadap lingkungan yang berbeda; dan setiap perubahan ditunjukkan oleh perbedaan ukuran garis truss. Dengan demikian adanya perbedaan bentuk bangun tubuh antarpopulasi memberikan gambaran bahwa masingmasing populasi telah mengembangkan keragaman sebagai respons terhadap lingkungan (Via \& Lande 1985).

Pada Gambar 3. terlihat bahwa populasi Tentena membentuk bangun tubuhnya secara mandiri tidak memperoleh komponen dari popu- 
lasi lain, kecuali karakter umum. Dari dendrogram yang terbentuk dapat dijelaskan bahwa populasi Tentena mempertahankan bentuk dasar, sedangkan populasi lain beradaptasi dan merubah karakternya sesuai dengan lingkungannya. Namun dari sisi lain, populasi Tentena mungkin berkembang secara spesifik menyesuaikan lingkungannya yang merupakan daerah pembuangan Danau Poso.

Menurut Reiss \& Grothues (2015), perubahan bentuk musiman dan hubungannya dengan variasi pola warna, kematangan seksual dan karakter morfologi, fisiologi dengan tingkah lakunya dapat dipengaruhi oleh kondisi ketinggian air. Sebagai contoh variasi morfologi pada C. temensis sebenarnya ditujukan untuk memperkirakan bahwa perbedaan karena spesies, subspesies atau suatu efek dari perbedaan kelamin. Selain itu perbedaan bangun tubuh ada hubungannya dengan pola penimbunan lemak dan penggunaannya, sedangkan perbedaan warna pada ikan tersebut ada hubungannya dengan musim kematangan gonad (Reiss et al. 2012).

Menurut definisi Kendal (1977), bentuk bangun tubuh adalah semua informasi geometrik yang ada tanpa pengaruh lokasi, sisik dan rotasi. Perubahan pada bentuk tubuh dapat dihitung jika dipisahkan dengan ukuran dan pengaruh alometrik. Sebagian besar variasi dikarenakan penimbunan lemak pada daerah yang spesifik (Arrington et al. 2002) dan terdapat sel adipose, implikasinya peningkatan penimbunan energi pada jaringan tersebut yang bertanggung jawab pada perubahan bentuk. Perubahan bentuk ada hubungannya dengan perkembangan pola warna dari tipis, bentuk hidrodinamis dari awal kematangan gonad dan hingga bentuk ekstrem pada stadia akhir kematangan gonad.

Pada Tabel 2 keragaman karakter garis (truss line) bisa berarti akan mengarah kepada perbedaan bentuk antarpopulasi sesuai dengan habitat yang ditempati. Berhubungan dengan pola temporal dalam skala besar dari variasi habitat, menurut Junk et al. (1989) dan Jepsen et al. (1999), bentuk tubuh populasi ikan mempunyai hubungan yang erat dengan siklus pasang surut air. Menurut Reiss et al. (2012), perubahan morfologi berhubungan dengan aspek mekanis bentuk anatomi hingga tingkah laku suatu organisme yang bisa saja dipengaruhi oleh musim atau kelimpahan air atau perubahan lingkungannya (Reis \& Grothues 2015).

Keeley et al. (2006) menjelaskan bahwa kondisi lingkungan dan perbedaan tipe ekologi (ekotipe) dapat memberikan proporsi perbedaan yang signifikan terhadap morfologi. Sehubungan dengan adanya perubahan lingkungan, maka perubahan genetik dapat berjalan seiring sesuai dengan intensitas lingkungannya. Hard et al. (1999) menjelaskan bahwa hubungan keragaman fenotipik terhadap radiasi adaptif dicapai melalui dua cara yakni dasar genetik dan konsekuensi fitness populasi dari variasi fenotipik. Artinya jika variasi fenotipik tersebut memberikan pengaruh yang nyata terhadap sintasan populasi, maka perubahan bentuk akan terus berlanjut.

Perbedaan morfologi tingkah laku atau daur hidup diantara populasi dihasilkan secara kombinasi dari respons kelenturan yang adaptif hingga lingkungan heterogen yang ekstrem. Contohnya ikan salmon (Onchorynchus myckis) yang memiliki keragaman morfologi dan tingkah laku yang berbeda. Adaptasi terhadap jenis makanan juga memberikan perbedaan morfologi yang signifikan. Misalnya ikan salmon yang memakan ikan, maka mulutnya akan berukuran lebih besar. Hal ini memberikan bukti bahwa perubahan berbasis genetik terhadap variasi morfologi berhubungan dengan lingkungan. Wademeyer (2001) menjelaskan bahwa fenotipe merupakan hasil interaksi 
antara genetik dan lingkungan. Artinya bahwa morfologi yang terbentuk merupakan hasil ekspresi genetik pada lingkungan tertentu. Menurut Arifin et al. (2015), variasi yang terdapat pada masing-masing karakter fenotipe bersifat tetap, merupakan ekspresi dari hasil interaksi antara genetik dan lingkungan.

Nilai percampuran komponen antarpopulasi (Tabel 2 dan Tabel 3) menunjukkan ekspresi gen dari alel yang sama antarpopulasi. Dengan demikian sharing component dari masing-masing populasi untuk populasi lainnya adalah karena terdapatnya alel yang sama antarpopulasi yang berbeda. Alel yang sama mengekspresikan jaringan atau organ yang sama dan membentuk karakter truss line yang sama. Jika ini terjadi pada semua populasi yang diamati berarti sharing component akan membentuk bentuk dasar spesies tersebut dalam semua populasi (Hadie et al. 2002).

Jarak genetik sebagai hasil penghitungan matriks karakter truss memberikan pemisahan antarpopulasi sampel yang diamati. Pemisahan secara genetik ini dimungkinkan oleh adanya sharing allele pada karakter truss antarpopulasi (Suparyanto et al. 1999). Gambar 3 dapat membantu seberapa erat atau jauh hubungan antarpopulasi atau dengan kata lain seberapa besar kesamaan atau perbedaan karakter truss satu populasi dengan populasi lain. Populasi 4 yang berasal dari Tentena secara morfometrik terlihat terpisah dari populasi lain. Hal demikian bisa terjadi karena kondisi lingkungan setempat, seperti kondisi air atau ketersediaan pakan alami (Keeley et al. 2006).

Perbedaan morfologi juga dapat dikarenakan oleh mekanisme gen kelenturan fenotipik (phenotypic plasticity gene) dapat dilihat sebagai variasi baik aditif maupun non aditif (Hadie et al. 2004). Kelenturan fenotipik, adalah kemampuan suatu individu atau genotipe untuk menghasilkan lebih dari satu alternatif bentuk morfologi, status fisiologis dan atau tingkah laku sebagai respons terhadap perubahan kondisi lingkungan (westEberhard, 1989; Via, 1993; Scheiner \& Lyman, 1989; Schneider et al. 2014. Keragaman atau variasi pada morfologi diantara ikan salmon secara kuat dipengaruhi oleh perbedaan genetik $52,7 \%$ sedangkan oleh ekotipe hanya 7,3\%. Penerapannya menurut Robinson \& Parsons (2002), banyak keragaman diantara koleksi ikan di alam dipengaruhi oleh dasar genetik yaitu kelenturan fenotipik sebagai respons perbedaan lingkungan. Kelenturan fenotipik juga ikut meningkat sebagai sumber variasi dalam karakter morfologi yang diamati diantara dan antarpopulasi. Laporte et al. (2016) dalam penelitiannya juga menghasilkan kesimpulan bahwa bentuk ikan berubah sebagai respons terhadap aliran air tanpa perubahan kecepatan tumbuhnya. Ikan dengan kecepatan aliran tinggi akan terlihat ramping dengan sirip ekor yang lebih panjang. Kandidat gen yang memiliki beberapa kategori fungsional ini memainkan peranan yang dinamis terhadap pola ekspresi gen yang secara konsisten menghasilkan morfologi yang beragam dan diduga ikut andil dalam memulai kelenturan fenotipik.

Gambar 6 juga memberikan informasi yang menarik sehubungan dengan kedekatan populasi dan alur aliran gen antarpopulasi. Tingkat homologi nukleotida dari lima sampel (Tabel 4) memperlihatkan tingkat kesamaan yang tinggi. Hal ini memperlihatkan bahwa antarpopulasi dari tiga lokasi yang berbeda masih mempertahankan gen dasar yang sama, atau dengan kata lain belum menunjukkan karakter gen yang berbeda antar ketiga lokasi tersebut.

Perubahan secara morfologi dan genetika pada umumnya seiring, namun laju perubahannya tidak linier. Pada umumnya perubahan morfologi jauh lebih cepat dibanding dengan peru- 
bahan secara genetika. Perubahan yang awal terjadi adalah kelenturan fenotipik (phenotypic plasticity) sebagai tahapan adaptasi terhadap perubahan lingkungan (Schlichting \& Pigliucci 1995). Kelenturan dapat berkembang dengan cepat setelah kolonisasi lingkungan baru sebagai respons terhadap perubahan lingkungan atau pemanfaatan sumber daya (Muschick et al. 2011). Hal yang sama juga terjadi pada populasi ikan rono di Danau Poso. Ada perubahan bangun tubuh yang berbeda terutama populasi Tentena dengan populasi lainnya, namun demikian secara genetik jarak genetiknya rendah. Pola demikian berlaku bagi beberapa hewan akuatik termasuk ikan, gastropoda, dan krustasea (Parson 1997) yang juga dapat digunakan sebagai mekanisme bertahan terhadap predator (Dodson 1989, Holopainen et al. 1997).

\section{Implikasi keragaman genetik untuk konservasi}

Kondisi populasi ikan rono di Danau Poso saat ini berdasarkan hasil evaluasi secara morfometrik dan molekuler dapat digunakan sebagai acuan dalam menyusun strategi konservasi ikan tersebut. Secara morfometrik ketiga populasi Tolambo, Taipa, dan Tentena masih memiliki kesamaan bentuk bangun tubuh sebesar 46,15\% (12 karakter dari 26 karakter yang dianalisis). Artinya bahwa ketiga populasi tersebut masih mempertahankan 12 karakter (truss line) sebagai bentuk dasar ikan rono di Danau Poso. Namun demikian secara molekuler, tingkat homologi nukleotida ketiga populasi berkisar antara 92,11\% dan $100 \%$. Artinya perubahan bentuk hanya merupakan adaptasi dari kondisi lingkungan setempat tanpa merubah keragaman genetik secara nyata atau dengan perkataan lain, perubahan genetik belum mengarah kepada spesiasi. Nilai percampuran (sharing component) pada Tabel 4 memperlihatkan adanya andil karakter sebesar 10-
$30 \%$ antara populasi Taipa dan Tolambo sedangkan populasi Tentena tidak memberi andil kepada populasi lainnya.

Oleh karena itu strategi konservasi ikan rono sebagai ikan endemik diharapkan bisa mengembalikan kepada bentuk dasar ikan rono dengan unggun gen (gene pool) yang utuh. Cara pertama yang dapat ditempuh adalah dengan membuat pemijahan silang antarpopulasi secara terkontrol dengan nilai $\mathrm{N}_{\mathrm{e}}$ minimal 500 yang dilakukan secara in situ. Cara kedua yaitu mengintroduksikan induk antarpopulasi sebanyak 1000 ekor dengan perbandingan betina dan jantan $1: 1$, dari populasi Tentena ke populasi Taipa dan Tolambo dan sebaliknya. Cara ketiga adalah kegiatan domestikasi ex situ dengan mengingat standar induk minimal >500 ekor dan selanjutnya melakukan penebaran kembali (restoking).

Strategi konservasi suatu jenis, termasuk jenis endemik seperti halnya ikan rono memerlukan pendekatan yang menyeluruh meliputi faktor nilai intrinsik maupun nilai ekstrinsik, namun unsur utama yang tetap diperhatikan adalah keragaman genetik dan aliran gen antarpopulasi. Ikan rono sebagai ikan endemik di Danau Poso (Gundo et al. 2015), membutuhkan perhatian khusus dan untuk mempertahankan populasi lestarinya diperlukan perhatian para pihak. Strategi konservasi ikan rono dapat dilakukan secara in-situ dan ex-situ. Konservasi in-situ meliputi perlindungan populasi/habitat, pemijahan buatan dan mempertahankan aliran gen antarpopulasi, sedangkan konservasi ex situ memerlukan komponen pemijahan buatan, restoking terprogram, pertukaran gen antarpopulasi dan introduksi ikan rono ke danau lain yang memiliki tipe yang sama. Kedua macam strategi konservasi tersebut perlu didukung aspek legal seperti Undang-undang, Peraturan Pemerintah, dan Peraturan Daerah. 
Konservasi ex-situ memerlukan pemijahan ikan secara alami maupun buatan di luar habitatnya. Untuk memelihara aliran gen antarpopulasi pada konservasi ex-situ dapat dilakukan dengan penebaran silang antarpopulasi dari hasil pemijahan buatan. Pada konservasi in-situ, untuk mempertahankan keragaman genetik secara total maka pemijahan secara komunal dapat dilakukan sehingga pertukaran gen antarpopulasi yang berbeda dapat berjalan dengan baik. Namun demikian jumlah induk efektif (effective breeding number $/ \mathrm{N}_{\mathrm{e}}$ ) yang digunakan untuk pemijahan secara komunal harus memadai secara ilmiah agar tidak terjadi hanyutan gen (genetik drift) yang menyebabkan bottle neck (Falconer \& Mackay 1996).

Ketentuan jumlah induk yang digunakan dalam upaya mempertahankan keragaman genetik ikan di perairan sangat berbeda dipengaruhi oleh jenis ikan, cara reproduksi, dan dan kemudahan perjumpaan untuk kawin dalam kerabat dekat. Berbeda dengan ikan air tawar, diduga ikan laut tidak mungkin memijah dengan kerabat dekat karena efek penyebaran populasi yang sangat luas dan kecenderungan gerakan atau percampuran reproduktif yang rendah. Jumlah induk yang efektif $\left(\mathrm{N}_{\mathrm{e}}\right)$ di alam untuk waktu 1-2 tahun sangat kecil, tercatat berkisar antara 65 dan 289 individu (O'Leary et al. 2013).

Di alam bebas jumlah secara pasti berapa ekor induk efektif untuk memelihara keragaman gen dalam populasi dipengaruhi oleh spesies, tipe kawin, pergerakan populasi dan luasan perairan. Jika pemijahan dilakukan secara ex situ atau pemijahan buatan, maka jumlah individu sangat bervariasi antara 50-1000 ekor dengan nisbah kelamin betina dan jantan 1:1. Jumlah induk efektif untuk mempertahankan keragaman gen adalah: 50-500 ekor (Primark et al. 1998), 263685 ekor (Tave 1986), 500 ekor (FAO/UNEP
1981), 1000 ekor (US Fish and Wildlife Service 1984), 200 ekor (Kincaid 1977) dengan tujuan untuk mengurangi laju silang dalam (Falconer \& Macay 1996).

Spesies langka dan endemik dapat menjadi indikator yang baik untuk memantau keberhasilan manajemen keanekaragaman hayati di kawasan lindung (Burlakova et al. 2014). Kombinasi antara kelimpahan informasi dan status langka tidaknya biota adalah alat yang sangat berguna untuk menunjukkan kegagalan atau keberhasilan dalam manajemen konservasi, tetapi juga untuk menunjukkan tindakan konservasi yang lebih efektif. Tantangan selanjutnya bagi ikan rono sebagai spesies endemik di danau Poso adalah introduksi spesies. Introduksi spesies eksogenus kedalam komunitas ekologi, mengakibatkan beberapa spesies yang umum terganggu dan jarang terjadi, pola konsisten dari taksa tersebut dalam suatu ekosistem (Magurran 2004, Magurran \& Handerson 2010).

Spesies endemik dapat menjadi indikator yang baik dari populasi unik misalnya dengan banyak taksa yang langka dan juga dapat digunakan sebagai spesies kunci dalam upaya konservasi (Burlakova et al. 2011). Artinya jika spesies kunci ini hilang, maka proses ekosistem yang rentan juga menjadi tidak berarti, menunjukkan bahwa spesies yang jarang (rare) dapat memengaruhi ketahanan ekosistem dan resiliensi jangka panjang (Smith \& Knapp 2003).

Ketika menetapkan kawasan konservasi, indikator kelangkaan dapat digunakan untuk memantau perubahan pola keanekaragaman hayati dalam skala ruang dan waktu, ini dapat menunjukkan kegagalan atau keberhasilannya dalam pengelolaan konservasi. Daerah yang dilindungi dan tersedia indikator ekologis biasanya keberhasilan konservasi akan semakin tinggi. Namun demikian informasi dasar tentang keberadaan 
dan persebaran spesies, serta tingkat kelangkaan dan endemisitas juga harus dimiliki. Sayangnya data seperti itu masih langka di daerah konservasi prioritas di Brasil (Teshima et al. 2015). Hal ini dapat digunakan sebagai contoh untuk menyusun strategi konservasi sumber daya ikan di Indonesia.

Beberapa penelitian telah secara konsisten mendokumentasikan bagaimana pengaruh kondisi lingkungan terhadap kekayaan spesies dan kelimpahannya (Walsh et al. 2005, Casatti \& Castro 2006, Teresa \& Casatti 2012). Manfaatnya mempertahankan atau mempromosikan heterogenitas lingkungan menjadi prioritas manajemen dalam rangka meningkatkan probabilitas species persistens dan spesialis. Endemisme dapat menjadi indikator yang baik bagi struktur populasi (Burlakova et al. 2011). Jika suatu spesies memiliki daerah persebaran yang rendah itu mungkin menunjukkan kebiasaan spesialis, sehingga spesies ini akan rentan terhadap hilangnya daerah habitat dari keperluan antropogenik. Rendahnya keragaman genetik mengakibatkan fitness yang rendah di masa depan, karena tidak mampu bertahan pada perubahan lingkungan akibat dampak yang ditimbulkan manusia, spesies asing invasif eksotis atau perubahan iklim. Evaluasi hal lain tentang spesies endemik terkait dengan persebaran, kelimpahan atau biomassa dapat membantu mengarahkan program konservasi yang lebih efektif untuk melestarikan kelompok spesies.

\section{Simpulan}

Populasi ikan rono di Danau Poso secara morfometrik dan molekuler memiliki keragaman yang berbeda. Secara morfometrik terdapat 12 karakter $(46,15 \%)$ menjadi karakter dasar dari tiga populasi, sebanyak tiga karakter $(11,54 \%)$ diduga akan menjadi karakter yang beradaptasi terhadap lingkungan dan 11 karakter truss (42,31\%) telah beradaptasi dengan lingkungan yang membedakan populasi satu dengan lainnya.

Secara molekuler populasi Tentena terpisah dari populasi lainnya yang berarti memiliki perbedaan dengan populasi lain pada tingkat DNA. Secara umum populasi Tentena memiliki keragaan populasi yang berbeda dengan populasi lain pada tingkat fenotipe dan genotipe. Strategi konservasi ikan rono perlu memulihkan kembali keragaman gen total/unggun melalui perkawinan silang antartiga populasi yang berbeda sehingga terjadi aliran gen dan memiliki unggun gen secara utuh, meningkatkan fitness dan menjaga populasi ikan rono sebagai jenis endemik tetap lestari.

\section{Daftar pustaka}

Arifin OZ, Subagja J, Hadie W. 2015. Karakterisasi biometric tiga populasi ikan semah Tor douronensis (Valensiannes, 1842) dalam mendukung konservasi sumber daya genetik. Jurnal Iktiologi Indonesia, 15(2): 143-154.

Arrington DA, Winemiller KO, Davidson BK, Lyman AC. 2006. Influence of life history and seasonal hydrology on lipid storage in three Neotropical fish species. Journal of Fish Biology, 68(5): 1347-1361.

Burlakova LE, Karatayev, AY, Pennuto C, Mayer C. 2014. Changes in Lake Erie benthos over the last 50years: Historical perspectives, current status, and main drivers. Journal of Great Lakes Research, 40(3): 560-573

Burlakova LE, Karatayeva AY, Karatayevc VA, Mayd ME, Bennette DL, Cooke MJ. 2011. Endemic species: Contribution to community uniqueness, effect of habitat alteration, and conservation priorities. Biological Conservation, 144(1): 155-165.

Dodson S. 1989. Predator-induce reaction norms. Bioscience, 39(7): 447-452.

Falconer DS, Mackay TFC. 1996. Introduction to Quantitative Genetics. $4^{\text {th }}$ Ed. Longman, Malaysia. 464 p.

FAO/UNEP. 1981. Conservation of the genetics resources of fish: Problems and recommendations. Report of the expert consultation on the genetic resources of fish. Rome, 9-13 
June 1980. FAO Fisheries Technical Paper No. 217: 43 p.

Casatti L, Castro RMC. 2006. Testing the ecomorphological hypothesis in a headwater riffles fish assemblage of the rio São Francisco, southeastern Brazil. Neotropical Ichthyology, 4(2): 203-214.

Gundo MT, Rahardjo MF, Lumban Batu DTF, Hadie W. 2013. Dimorfisme seksual dan mikroanatomi ovarium ikan endemik rono (Adrianichthys oophorus, Kottelat 1990) di Danau Poso Sulawesi Tengah. Jurnal Iktiologi Indonesia, 13(1): 55-65.

Hadie W, Sumantadinata K, Carman O, Hadie LE. 2002. Pendugaan jarak genetik populasi udang galah (Macrobrachium rosenbergii) dari Sungai Musi, Sungai Kapuas, dan Sungai Citanduy dengan truss morphometric untuk mendukung program pemuliaan. Jurnal Penelitian Perikanan Indonesia, 8(2): 18.

Hadie W, Sumantadinata K, Noor RR, Subandriyo, Carman O, Hadie LE. 2004. Kelenturan fenotipik udang galah (Macrobrachium rosenbergii) strain Musi, Barito, GIMacro, dan persilangannya pada lingkungan bersalinitas. Jurnal Penelitian Perikanan Indonesia, 10(5): 33-46.

Hard JJ, Winans GA, Richarson JC. 1999. Phenotypic and genetik architecture of juvenile morphometry in chonook salmon. Journal of Heredity, 90(6): 597-606.

Holopainen IJ, Aho J, Vornanen M, Huuskonen H. 1997. Phenotypic plasticity and predator effects on morphology and physiology of crucian carp in nature and in the laboratory. Journal of Fish Biology, 50(4): 781-798.

IUCN. 2010. IUCN Red List of Threatened species. Version 2010.4. IUCN, Gland, Switzerland and Cambridge, UK.

Jepsen DB, Winemiller KO, Taphorn DC, Olarte DR. 1999. Age structure and growth of peacock chiclids from rivers and reservoirs of Venezuela. Journal of Fish Biology, 55(2): 433-450.

Junk WP, Bayley PB, Spark RE. 1989. The flood pulse concept in river-floodplain systems. In: Dodge DP (editor). Canadian Special Publication of Fisheries and Aquatics Sciences, Volume 106: 110-127.

Keeley ER, Parkinson EA, Taylor EB. 2006. The origins of ecotypic variation of rainbow trout: a test of environmental vs. genetikally based differences in morphology. Journal of Evolutionary Biology, 20(2): 725-736.

Kendal D. 1977. The diffusion of shaped. Advances in Applied Probability, 9(3): 428-430.

Kincaid HL. 1977. Rotational line crossing: An approach to the reduction of inbreeding accumulation in trout brood stocks. Progresive Fish-Culturist, 39(4): 179-181.

Kirkpatrick M, Selander RK. 1979. Genetics of speciation in Lake Whitefishes in the Allegash Basin. Evolution, 33(1): 478-485.

Laporte M, Claude J, Berrebi P, Perret P, Magnan P. 2016. Shape plasticity in response to water velocity in the freshwater blenny Salaria fluviatilis. Journal of Fish Biology, 88(3): 1191-203.

Magurran AE. 2004. Measuring Biological Diversity. John Wiley \& Sons. Blackwell Science Ltd, Blackwell Publishing Company, Cowley Road, Oxford OX4 1JF, UK. 264 p.

Magurran AE, Handerson PA. 2010. Temporal turnover and the maintenance of diversity in ecological assemblages. Philosophical Transaction of Royal Society B, 365: 3611-3620

Muschick M, Barluenga M, Salzburger W, Meyer A. 2011. Adaptive phenotypic plasticity in the Midas cichlid fish pharyngeal jaw and its relevance in adaptive radiation. $B M C$ Evolutionary Biology, 11(116): 1-12.

O' Leary SJ, Hice LA, Feldheim, KA, Frisk MG, McElroy AE, Fast MD, Chapman DD. 2013. Severe inbreeding and small effective number of breeders in a formerly abundant marine fish. PLoS ONE, 8(6): e66126

Parson KE. 1997. Role of dispersal ability in the phenotypic differentiation and plasticity of two marine gastropods. I. Shape. Oecologia, 110(4): 461-471

Primark RB, Supriatna J, Indrawan M, Kramadibrata P. 1998. Biologi Konservasi. Yayasan Obor Indonesia, Jakarta. 345 p.

Rahardjo MF, Sjafei DS, Affandi R, Sulistiono. 2010. Iktiologi. Lubuk Agung. Bandung. $396 \mathrm{hlm}$.

Rahardjo MF. 2015. Ikan endemik Danau Poso. Masyarakat Iktiologi Indonesia. http: //iktiologi-indonesia.org/ikan-endemikdanau-poso. Diakses 1 Mei 2017. 
Reiss P, Grothues TM. 2015. Geometric morphometric analysis of cyclical body shape changes in color pattern variants of Cicla temensis Humboldt, 1821 (Perciformes: Cichlidae) demonstrates reproductive energy allocation. Neotropical Ichthyology, 13(1): 103-112.

Reiss P, Able KW, Nunes MS, Hrbek T. 2012. Color pattern variation in Cichla temensis (Perciformes: Cichlidae): Resolution based on morphological, molecular, and reproductive data. Neotropical Ichthyology, 10(1): 59-70.

Robinson BW, Parsons KJ. 2002. Changing times, spaces, and faces: tests and implications of adaptive morphological plasticity in the fishes of nortjern postglacial lakes. $\mathrm{Ca}$ nadian Journal of Fisheries and Aquatic Science, 59(11):1819-1833.

SAS Institute Inc. 1997. SAS User Guide: Statistics, Version 6.12 Edition, Cary, NC. USA. $956 \mathrm{p}$.

Scheiner SM, Lyman RF. 1989. The genetics of phenotypic plasticity. I. Heritability. Journal of Evolutionary Biology, 2(2): 95-107.

Schlichting CD, Pigliucci M. 1995. Gene regulation, quantitative genetics and the evolution of reaction norms. Journal of Evolutionary Ecology, 9(2): 154-168.

Schneider RF, Li Y, Meyer A, Gunter HM. 2014. Regulatory gene networks that shape the development of adaptive phenotypic plasticity in a cichlid fish. Molecular Ecology, 23(18): 4511-4526

Schluter D. 2000. Ecological character displacement in adaptive radiation. The American Naturalist, 156(4): S4-S16

Smith MD, Knapp A. 2003. Dominant species maintain ecosystem function with nonrandom species loss. Ecology Letters, 6(6): $509-517$.

Staufer JR, Gray EVS. 2004. Phenotypic plasticity: its role in trophic radiation and explosive speciation in cichlids (Teleostei: Cichlidae). Animal Biology, 54(2): 137-158.
Suparyanto A, Purwadaria T, Subandriyo. 1999. Pendugaan jarak genetik dan factor peubah pembeda bangsa dan kelompok domba di Indonesia melalui pendekatan analisa morfologi. Jurnal Ilmu Ternak dan Veteriner, 4(1): 80-87.

Tave D. 1986. Genetics for Fish Hatchery Managers. AVI. Publishing Company. 299 p.

Teresa FB, Casatti L. 2012. Influence of forest cover and mesohabitat types on functional and taxonomic diversity of fish communities in Neotropical lowland streams. Ecology of Freshwater Fish, 21(3): 433-442.

Teshima FA, Ferreira FC, Cetra M. 2015. Rarity status of endemic and vulnerable fish species in a Brazilian Atlantic Forest protected area. Natureza Conservacio - Brazilian Journal of Nature Conservation, 13(1): 67-73

United State Fish and Wildlife Service. 1984. Minimum number of parents needed to protect genetic stability in fish brood stocks. US Government Printing Office.

Via S, Lande R. 1985. Genotype-environment interaction and the evolution of phenotypic plasticity. Evolution, 39(3): 505-522.

Via S. 1993. Regulatory genes and reaction norms. The American Naturalist, 142(2): 374-378.

Wademeyer GA. 2001. Fish Hatchery Management $2^{\text {nd }}$ ed. American Fisheries Society. Bethesda, MD. 733 p.

Walsh CJ, Roy AH, Feminella JW, Cottingham PD, Groffman PM, Morgan RP. 2005. The urban stream syndrome: current knowledge and the search for a cure. Journal of the North American Benthological Society, 24(3): 706-723.

Ward DR, Zemlak TS, Innes BH, Last PR, Hebert PDN. 2005. DNA barcoding Australia's fish species. Philosophical Transactions of the Royal Society B, 360(1462): 1847-1857.

West-Eberhard MJ. 1989. Phenotypic plasticity and the origins of diversity. Annual Review of Ecology and Systematics, 20: 249-278 